\title{
Finding the balance. The role of Australia-Japan cooperation in the shaping of the Asia-Pacific security architecture
}

\section{Introduction}

The concept of a regional security architecture evokes a wide discussion among scholars and policy makers. Consensus has been reached neither on the elements constituting such an architecture nor on its preferable structure. Some emphasise the role of informal cooperation agreements among the participating states while others stress the importance of effective international institutions (Murray 2010, 5-6). The case of the region of East Asia and the Pacific, which is recently undergoing rapid changes in its international order, seems to be particularly interesting in this regard. The emerging multilateral order, new rising major powers and the shift of power towards the East cause clashes of security interests among the regional players. This is additionally strengthened by the existing division into 'Western' and 'Eastern' states. The very first problem faced while addressing the issue of regional security architecture is that the borders of the region should be defined precisely. In the given case, however, there are two competing visions of regional integration, namely the more closed East-Asian regional community that is dedicated exclusively to East Asian states (that is China, Japan, the Republic of Korea and the ASEAN states) versus the rather open Asia-Pacific regional community that includes other players like the United States, Australia, New Zealand, India and Russia. The international institutions and bodies existing already in this region are both open and closed, and their membership and competences are changed in accordance with the recent needs (Murray 2010, p. 5-6).

The security interests of the 'Western' states, namely the United States, Australia, New Zealand and sometimes also Japan, are located mostly in East Asia. Therefore those countries are determined to preserve their presence in East Asia and pursue the concept of an open Asia-Pacific regionalism not only in economic affairs (in which it has been institutionalised in form of APEC), but in the security issues as well. Due to the fact that the security environment in the Asia-Pacific 
region is rapidly changing, the post-Cold War security architecture based on the strong military presence of the United States and their network of bilateral alliances is ill suited to face the new challenges. It forces the secondary powers, namely Japan and Australia, to engage more independently in the regional security affairs and re-shape the old order.

This paper argues that Australia and Japan, taking a cooperative approach, are able to successfully re-shape the regional security architecture in the AsiaPacific. Due to their ambiguous characteristics of being 'in-between' the East and the West, they are equipped with a unique set of tools allowing them to enhance the regional security cooperation framework. However, the question that remains is that of the shape of the potential cooperation and to what extent it would reflect the different - and sometimes contradicting - interests of regional players. The role of institutionalisation in the successful functioning of the security structure is discussed as well.

\section{New major trends in the security environment}

Until recently the security environment of the Asia-Pacific region has been mostly defined by the U.S.-centred structure of hub-and-spokes. Its roots can be traced back to the beginning of bipolar rivalry of the Cold War era, when the main source of threat to the regional stability was the activity of the countries affiliated with the Soviet Union. The hub-and-spokes structure, consisting of bilateral alliances of the non-communist countries of the Asia-Pacific (not only with Japan, but also the Republic of Korea, Thailand and the Philippines) with the United States, as well as the trilateral ANZUS alliance (with Australia and New Zealand), was designed to contain and respond to traditional threats and it served its purpose rather well. The end of the Cold War period brought with itself a relative rise in the security perception in the region as the possibility of state-with-state war decreased. Nevertheless, states were still perceived as the main factors influencing the security in the Asia-Pacific.

Recently however, since numerous new trends in the regional security environment can be observed, the hub-and-spokes structure seems not to be well fitted in the recent security environment, despite remaining as the major institutionalised security structure in the region. Two major factors now reshape the regional order, which indicates a structural change, namely the rise of China's influence in the region and the growing importance of non-traditional security threats (Jae 2011, p. 138).

Both China's (i.e. the People's Republic of China) growing presence in the region and its significance to the Asia-Pacific security structure is nothing new; on the contrary, the security architecture of Asia-Pacific states was Sinocentric until the $19^{\text {th }}$ century. The U.S.-centred structure created after the Second 
World War, resulting from Chinese internal and external weakness, must have been only temporary, even if it was not perceived as such at that time (Lyon 2009, p. 2).What is the new factor is the power shift from Washington to Beijing, especially visible since the beginning of the world financial crisis of 2008, which in this case is both a turning point and a cause of this shift. The financial weakness of the United States not only challenged their role as the core of the regional security structure, but also created a place for China to develop its regional presence as the new leader and the representative of the smaller states in the Asia-Pacific. Taking this opportunity, China has expanded its position in international bodies, demanding that institutions such as the World Bank and the International Monetary Fund strengthen their supervisory and regulatory functions, which evoked region-wide support (Thayer 2010, p. 7-8). However, Beijing not only expands its institutional security base, but also invests in the modernisation of its army and navy. The growing military expenditures are not received well by other countries in the region, casting doubts on China's image of a 'responsible stakeholder' implementing the strategy of 'peaceful growth' and resulting in rising tensions among other regional players. On the one hand the United States, unwilling to surrender their leading position to China, makes serious efforts to stabilise their presence in the Asia-Pacific security affairs. The Obama administration has made numerous gestures, especially towards the Southeast Asian states, appointing this region as the new 'pivotal point' of their external policy. As both security and economic interests of the United States are placed in East Asia, Washington is determined to preserve the Asia-Pacific security architecture to be as inclusive as possible (Tow 2012, p. 2-3). On the other hand, China's rising armament and military modernisation prompt other Asian states to significantly increase their military expenditures as well (Holtom2010, 4). The lack of transparency in Chinese armaments, the uncontrolled diffusion of military technology in the region and, first and foremost, the uncertainty regarding Beijing's intentions (Thayer 2010, p. 35-38) lead to an emerging security dilemma in the region.

The second key factor influencing and reshaping the Asia-Pacific security structure isnon-state security threats. Due to the vast diversity characterising this region in all dimensions (including historical, cultural and religious background, ethnic diversity, level of economic development and political system), the significance of non-traditional security threats is not only far greater there than commonly perceived, but also growing. The most essential aspects of the new security order, typical mostly for Southeast Asian states, are non-state transnational security threats (e.g. international criminal groups, pandemics, environmental issues) and the risk of domestic conflicts (usually caused byethnic or religious irredentist groups). If unaddressed, these issues will continue to cause instability in the region, as well as pose a serious threat to the existing cooperative institutions, such as ASEAN (Thayer 2010, p. 11). 
All the tendencies named above have one essential trait in common; they encourage the Asia-Pacific states to further engage in regionalism. Since none of the emerging issues could be approached unilaterally or even by a multilateral alliance, both the major powers and the secondary players, among which are both Japan and Australia, turn towards region-wide cooperation in the security issues.

\section{Different visions, different interests: Japan and Australia}

Even if the need for regional cooperation is evident, until now there has been no common vision regarding the shape of the regional security order. The proposals presented up till now, among which the Australian and Japanese ones were the most complex and detailed, have evoked international controversies and a critical rather than welcoming receipt. Moreover, they have indicated a vast discrepancy in the regional security visions between Tokyo and Canberra.

Chronologically first was the design of the regional security order presented in 2008 by Australian Prime Minister Kevin Rudd during his visit in Singapore. In his speech he expressed the intention to establish by 2020 a wide, inclusive AsiaPacific Community (APC) that would have a strongly institutionalised structure empowered to address non-traditional security threats, such as pandemics, natural disasters and environmental issues, food security and international criminal groups. At the core of the Australian proposition was the belief that the security structure of Asia-Pacific region should be based on strong and effective international institutions, following the patterns of institutionalisation in the European Union. APC was also designed for relatively wide membership, aiming for securing the Australian presence in the region, as well as preserving the engagement and the leading role of the United States in the East Asia .

A counterproposal was issued next year by Japanese Prime Minister, Hatoyama Yukio. He called for the establishment of the East Asian Community (EAC), far less institutionalised and formalin comparison to the Australian project. According to the Japanese proposal, a gradual approach should be taken in establishing a community in the region. With relatively well developed economic relations as a starting point, the regional players should intensify their collaboration in the field of security as well, focusing on particular issues, which would finally lead to institutionalisation of the regional cooperation. The Japanese proposal also referred to the European regionalism. However, Hatoyama emphasised the role of the post-war reconciliation between France and Germany, drawing a parallel to the historical tensions between Japan and China. In his vision, the regional security structure was restricted to East Asia, with its core being the strong Sino-Japanese cooperation. Although it was not clearly stated, both the United States and Australia (as well as the New Zealand) were to be excluded from the EAC. 
Regardless of the differences between the Rudd and Hatoyama proposals, both of them evoked a strong wave of criticism from the other regional players. The main reproach to both projects was that they were presented without any preparatory groundwork or international consultations, therefore causing surprise and confusion. Such a unilateral approach of Australia and Japan, as well as their relative vagueness in terms of membership in the respective projected institutions, caused a feeling of exclusion among other countries in the region. The ASEAN states especially critiqued the Rudd proposal, perceiving it as an attempt to brush aside the Association's self-appointed role of the pivot of the regional integration processes (Koh 2009).Moreover, the concept of APC was received negatively among scholars who argued that a new institution would be redundant and overlapping with the already existing East Asia Summit.

The Hatoyama proposal, calling for greater independence from the United States, received similar critique from both Washington and Canberra, protesting against their exclusion from the regional security order (Cook 2009). However, the reduced presence of the United States in the intended institution worried the ASEAN countries as well; they expressed the concern that with the Sino-Japanese alliance as the core of the EAC, with no other major power present, China would dominate the structure. Ironically, the essential role of the United States as a balancer to the emerging Chinese potential was stressed especially by Vietnam (Energy Daily: 2012).

Beijing's response to both initiatives was moderate and did not indicate any will to engage in either of them. The Hatoyama proposal, however, was received slightly more favourably due to its focus on East Asia (and not the Asia-Pacific), its emphasis on the reconciliation in Sino-Japanese relations (Yang and Lim, p. 62), as well as the exclusion of the United States from the projected institution (Hemmings 2010).

Neither Australian nor Japanese project of regional security architecture has been successfully implemented and the region-wide debate they have prompted has not reached a meaningful conclusion. What is more, the Rudd and Hatoyama proposals showed vast discrepancies in Australian and Japanese interests towards the regional players, namely China and ASEAN.

For Japan the most important political and economic ties are with ASEAN. Tokyo not only supported the idea of Southeast Asian integration from the very beginning, but also cooperates with ASEAN closely in various dimensions and supports it both politically and financially (in form of investments and Official Development Aid). Moreover, the Association as a whole is the second largest trading partner of Japan (after China). The value of trade between both partners in 2010 totalled up to 103,1 milliard USD, with the balance of trade slightly to Japan's advantage (The ASEAN Secretariat 2012).Consequently, Tokyo perceives the rising presence of China in the Southeast Asia as threatening to its own strong position. 
Beijing's increasing engagement in Southeast Asian affairs only adds to existing historical and political tensions, troubling their already complicated bilateral relations. Therefore keeping China's influence in the region contained, using the strategy of balancing its presence with the other major powers' engagements is stressed as an important goal of Japanese foreign policy (Lyon 2011b, p. 5-6).

In contrast to Japan, Australia's interests towards the other players in the AsiaPacific region are centred around China. Not only are the Australian-Chinese relations free from the historical burdens, which present a difficulty to the postwar reconciliation between Tokyo and Beijing, but also the emerging Chinese economy is perceived positively in Canberra, since it is complementary rather than competitive to the Australian one. Moreover, the rising China is Australia's largest trade partner and a significant buyer of Australia's main export products, namely iron ore, petroleum, coal and wool. In 2011 the value of bilateral trade between both countries totalled up to 110 million AUD, with the balance of trade in advantage to Australia Thomson 2012, p. 10-12). Therefore pulling Beijing in to a close cooperation is of a strategic interest to Australia.

However, Canberra's relations with the ASEAN countries are not as friendly as with China. The Association is only a minor economic partner to Australia, even though the complementarities of their economies and the access level to Australian markets increases gradually. The relatively low level of economic cooperation can be traced back to Canberra's economic protection policy in the 1970s and the aftermath of the Asian financial crisis in 1997, when ASEAN lost its credibility as a reliable trade and investment partner. In addition to that, there are historical burdens in Australia's relations with ASEAN's leading countries, namely Indonesia and Malaysia. At the beginning of 1990s Canberra's political relations with Kuala Lumpur were disturbed by a series of offensive newspaper publications mockingly depicting the culture, religion and internal affairs of Malaysia, which evoked a very strong critical response (StudyMode.com 2010). Relations with Jakarta were strained due to Australia's support for East Timor independence and its strong engagement in the UN-lead stabilisation mission (Frost 2008). Even though the cooperation with ASEAN is improving since 2004 and recently Australia is engaged in numerous economic, political and development initiatives (The ASEAN Secretariat), ties between these two partners remain not as strong as the Japanese-ASEAN ones.

\section{Reasons for security cooperation}

Considering such a wide discrepancy in political and economic interests and attitudes towards their East Asian partners, along with their different geopolitical situations and the different security threats they face, this would suggest a tug of war rather than cooperation between Australia and Japan. An additional negative 
factor is their long history of strained relations, especially during the Cold War era (Kikuchi 2007, p. 64-65).

However, in defiance of these negative factors both Australia and Japan perceive each other as strategic partners and emphasise the role of their cooperation as an important pillar of their security policy. Even though they are placed in different geopolitical spheres and they face different threats to their security, Japan and Australia gradually take a more integrated, regional approach to security, focusing on the new trends in the regional security environment. This attitude has its roots not only in the increasing transnational security threats, but also in a number of similarities and parallels that can be drawn between these two states.

Firstly, Australia and Japan both share the similar strategic experience of a close alliance with the United States and belonging to their hub-and-spokes strategy. On the one hand, the hub-and-spokes strategy has served its purpose well and structured the security sphere in the Asia-Pacific successfully, deferring the major regional threats. On the other hand, however, it becomes less and less adapted to the new security challenges faced by Australia and Japan (Bisley 2008, p. 38-39). Both countries are therefore in a similar situation, in which after decades of security dependence on the United States they have to take a proactive approach and shape their security environment themselves.

The second reason is their attitude towards the American presence in the region. Despite the fact that Australia and Japan have recently shown a penchant for a more independent policy, keeping the United States involved in the region is vitally important to both of them. The United States are not only the major stabilising power in the Asia-Pacific, but also have a well-developed network of task forces, specialised in combating the non-traditional threats. They are also the only state able to balance the rising Chinese influence. Ironically, the changing role of China in the region is an important factor pulling Australia and Japan into close cooperation as well. Even though their particular interests towards China differ vastly, Beijing's engagement in the Asia-Pacific is beneficial to both countries, as it accelerates economic cooperation within the region and contributes to the economic development in the less developed countries as well as enhancing the political dialogue. China's presence in the regional institutions, however, needs to be balanced; a regional security architecture dominated by one major power is to the advantage of neither Japan nor Australia.

Another parallel to be drawn between Japan and Australia is their similar perception among the other countries in the region. On the one hand they are perceived as 'partial outsiders' - geographically located in the Asia-Pacific region, but representing different cultural backgrounds and different identities. On the other, they are often labelled as 'American anchors' in the region - reactive states that only serve the interests of the United States. Their ambiguous international identity does not facilitate them engaging in East Asian institutions. Closer cooperation in the security dimension and further engagement in the regional 
security institutions would, however, be a clear sign to the other regional players that Australia and Japan are not only interested in developing the regional security structure, but also ready and able to pursue a policy independent from the United States.

The ambiguous international identity of Australia and Japan has also positive connotations. They perceive each other as partners not only because otherwise they could be rejected by East Asian countries, but also because they have a common foundation to build on. As they share similar values, such as liberal democracy or rule of law, along with the United States they create a small group of states in the Asia-Pacific that are 'defined by what they stand for' (Wilkins 2007, p. 266). For Japan and Australia the 'Western' values are in this case not an ornament, but an explicitly named base for their developing security cooperation (Bisley 2008, p. 39).

Even though the reasons encouraging the cooperation named above belong rather to the 'soft power' category, they still prevail in the assessment of Japan's and Australia's strategy toward each other. Their decision to take a cooperative approach is motivated both negatively - that is in order to counter-balance the rising China - and positively, by developing their independent and more mature foreign policy, free from the patterns of the Cold War era (Thomson 2007, p. 79-80). Furthermore, they both can not only better address the recent security challenges and strengthen their regional standing, but also forge their national and international identity. As mentioned before, Australia and Japan are internationally perceived as ambiguous states, neither 'Western' nor 'Asian', but more importantly, they have problems with defining their identity themselves, torn between 'the East' and 'the West'. Recently a policy shift towards East Asia can be observed (Lyon 2011a, p. 6-7). As both Australia and Japan place their vital interests in this region, they would prefer to define themselves as Asian states. By enhancing their security cooperation they would broaden their alliances and become more independent from the United States, which in turn would lead to greater openness in their regional policy and gain an approving response from the other regional players.

\section{Australia and Japan: shaping the Asia-Pacific security structure together}

Acknowledging the lack of consensus among the Asia-Pacific states regarding the elements and the future shape of the regional security structure, Japanese and Australian efforts should not be put into creating a security institution at present. Rather than that, they might gain more by enhancing the 'habit of cooperation' among the Asia-Pacific states and thus creating a bedrock for further institutionalisation (Carr 2012). The 'habit of cooperation' would increase the international stability not only by strengthening the already existing institutions, but also by 
allowing all the participating states to express and pursue their security interests. The emerging multilateral order in the Asia-Pacific would lead to a perpetual power play and mutual counter-balancing of influence by all parties. However, in order to preserve the relatively peaceful relations in the region as well as develop the regional security architecture, the needs of all participants should be properly addressed. Otherwise the regional integration would be perceived as directed against the marginalised party, leading to growing tensions.

Japan's and Australia's cooperation could make their contribution to the changing regional security architecture significant by strengthening the cooperative approach throughout the region. What makes it possible is their 'twowheel' engagement in the region, consisting of a combination of their stable alliances with the United States on the one hand and relatively deep engagement in East Asian regional institutions centred around ASEAN, such as APEC, ARF or EAS on the other. As mentioned before, two major trends affecting the Asia-Pacific security environment are the rise of China's presence and the non-traditional security threats. Combined with the two tools named above, a matrix of cooperative Australian-Japanese influence on the Asia-Pacific security architecture can be drawn.

In the case of the non-traditional security threats, the alliance with the United States enables Tokyo and Canberra to make an effective use of the well-developed action-oriented security network provided by the United States. What increases the effectiveness of their engagement however is their participation in the multilateral institutions centred around ASEAN, allowing them to identify the regional needs and successfully allocate the assets in accordance with them. The issue of the emerging China can be addressed with these two tools as well. Participation in multilateral institutions dedicated to different issues allows Japan and Australia to positively engage the growing Chinese potential to the benefit of the whole regional community, for example in various developmental projects. But to preserve the security structure from Beijing's domination, the presence of the United States hedges against the possibility of unbalancing the regional order, that is to exclude the Pacific powers from the process of regionalisation (Ishihara 2009, p. 104-106).

An important question arises how this gradual, multi-layered approach should be introduced. William T. Tow proposes a three-staged process, starting from defining the most desirable regional security architecture. To respond to all regional needs, such an architecture, while inclusive and pan-Asian, should facilitate ties among the particular sub-regions, that is Northeast Asia, Southeast Asia, South Asia and the Pacific. Moreover, it should present the opportunities to address the core issues for regional security (in both the traditional and non-traditional dimensions) and allow the heads of states or governments to consult and project policies on a regular basis. None of the recently existing international institutions 
is capable of fulfilling these tasks; it appears that a gradual integration of EAS and APEC into a new, multi-functional institution could be a right answer to this issue.

Secondly, the dilemma of Sino-Japanese relations must be addressed to ensure the regional stability. Using the preventive diplomacy on bilateral and multilateral levels appears to be a necessary means of reducing and eventually eliminating the cultural, historical and political tensions between Tokyo and Beijing. By coordinating their efforts, Japan and Australia could also approach the Taiwan issue in scope of their bilateral strategic dialogues with China.

Finally, Tokyo and Canberra have to increase their material commitment to the security matters and establish their response forces independently from the United States. In the new, more complex and consistently changing security environment Japan and Australia will be faced with challenges and threats, which will not justify the American intervention. To successfully defend their interests and reduce the uncertainty and insecurity in the Asia-Pacific, their military capability will have to become more self-reliant and more effective (Tow 2007, p. 32-34).

\section{Conclusion}

What is the most crucial to the developing security cooperation between Japan and Australia is finding the balance in a number of regards. Firstly, making good use of their unique 'two-wheel' policy, they need to strike a balance between bilateralism and multilateralism, which would allow them to keep all the interested parties engaged, as well as to reflect and address the regional power play. Even though clashes of interests are inevitable in a region as diverse as the Asia-Pacific, Australia and Japan need to find a point of equilibrium within the overlapping networks of interests so that none of the regional players is marginalised. Sustaining the regional stability and enhancing the cooperative attitude will slowly lead to the institutionalisation of a broad, effective and multi-functional security structure, since the recent tensions in the Asia-Pacific are not the consequence of ill-fitted institutions but rather the missing balance.

\section{References}

Bisley, Nick. (2008). "The Japan-Australia security declaration and the changing regional security setting: wheels, webs and beyond?". Australian Journal of International Affairs: 1.

Carr, Bob. (2012). "The East Asia Summit: Building our Regional Architecture for the 21st Century", The official webpage of the Australian Minister of Foreign Affairs. URL: < http://www. foreignminister.gov.au/articles/2012/bc_ar_120706.html> [accessed September 15, 2012].

Cook, Malcolm. 2009. ,Japan's East Asia Community”, The Interpreter, accessed September 8, 2012. URL: <http://www.lowyinterpreter.org/post/2009/09/25/Japane28099s-East-Asia-Community $. \operatorname{aspx}>$ [accessed September 15, 2012]. 
Energy Daily. (2012). “Ex Obama aide rips Japan's Hatoyama”, URL: <http://www.energy-daily. com/reports/Ex_Obama_aide_rips_Japans_Hatoyama_999.html $>$ [accessed September 15, 2012].

Frost, Frank. 2008. "ASEAN's regional cooperation and multilateral relations: recent developments and Australia's interests". Parliament of Australia Department of Parliamentary Services Research Paper. URL: <http://www.aph.gov.au/binaries/library/pubs/rp/2008-09/09rp12.pdf> [accessed September 15, 2012]

He Baogang. (2012). Rudd's proposal for an 'Asia-Pacific Community': Responses and criticisms, Institute of Strategic and International Studies: 3. URL: <http://www.isis.org.my/files/7thEAC/16-Prof-Baogang-He.pdf $>$ [accessed September 8, 2012].

Hemmings, John. (2010). “Understanding Hatoyama's East Asian Community idea”, East Asia Forum, http://www.eastasiaforum.org/2010/01/22/understanding-hatoyamas-east-asian-community-idea/> [accessed September 9, 2012].

Holtom, Paul et al. 2010. "Major trends in international arms transfers, 2009", SIPRI Fact Sheet.

Ishihara, Yusuke. (2009). "Partnership Adrift: Reshaping Australia-Japan Strategic Relations", Security Challenges: 1.

Jae Jeok Park. (2011). "The US-led alliances in the Asia-Pacific: hedge against potential threats or an undesirable multilateral security order?", The Pacific Review: 2.

Kikuchi, Tsutomu. (2007). "Review and prospects for the bilateral strategic relationship between Japan and Australia", The 4th Australia and Japan 1.5 Track Security Dialogue.

Koh, Tommy. (2009). "Rudd's reckless regional rush", The Australian, <http://www.theaustralian.com.au/opinion/rudds-reckless-regional-rush/story-e6frg6zo-1225811530050> [accessed September 8, 2012].

Lyon, Rod. (2009). "Changing Asia, rising China, and Australia's strategic choices", ASPI Policy Analysis: 40.

Lyon, Rod. (2011). "Forks in the river: Australia's strategic options in a transformational Asia", ASPI Strategy.

Lyon, Rod. (2011). “Japan's strategic outlook”, ASPI Special Reports: 44.

Murray, Philomena. (2010). "Regionalism and community Australia's options in the Asia-Pacific", ASPI Strategy.

StudyMode.com. (2010). "Factors Toward the Strain of Malaysia Australian Relations", $<$ http://www.studymode.com/essays/Factors-Toward-The-Strain-Of-Malaysia-439071.html> [accessed September 10, 2012].

Thayer, Carlyle A. (2010). "Southeast Asia. Patterns of security cooperation", ASPI Strategy.

The ASEAN Secretariat. (2012). „ASEAN-Australia Dialogue”, The ASEAN Secretariat, <http:// www.aseansec.org/12974.htm> [accessed September 10, 2012].

The ASEAN Secretariat. (2012). "ASEAN-Japan Dialogue Relations", , http://www.aseansec. org/5740.htm [accessed September 9, 2012].

The Economist. (2011). "We're back: America reaches a pivot point in Asia", <www.economist. com/node/21538803> [accessed September 8, 2012].

Thomson, Mark. (2007). "The Japan-Australia strategic relationship: an Australian perspective", The 4th Australia and Japan 1.5 Track Security Dialogue

Thomson, Mark. (2012). "Trade, investment and Australia's national security ...or how I learned to stop worrying and love Chinese money", ASPI Strategic Insights: 56.

Tow, William T. (2007). "Emerging Asia-Pacific security architectures: the Australia-Japan factor", The $4^{\text {th }}$ Australia and Japan 1.5 Track Security Dialogue.

Tow, William T. (2012). "The eagle returns: resurgent US strategy in Southeast Asia and its policy implications", ASPI Policy Analysis. 
Tow, William T., and Rikki Kersten. (2011). Evolving Australian Approaches to Security Architectures in the Asia-Pacific, The Tokyo Foundation, <http://www.tokyofoundation.org/en/ articles/2011/evolving-australian-approaches-to-security-architectures-in-the-asia-pacific > [accessed September 8, 2012].

Wilkins, Thomas S. (2007). 'Towards a 'Trilateral Alliance?' Understanding the Roles of Expediency and Values in American-Japanese-Australian Relations", Asian Security: 3. 